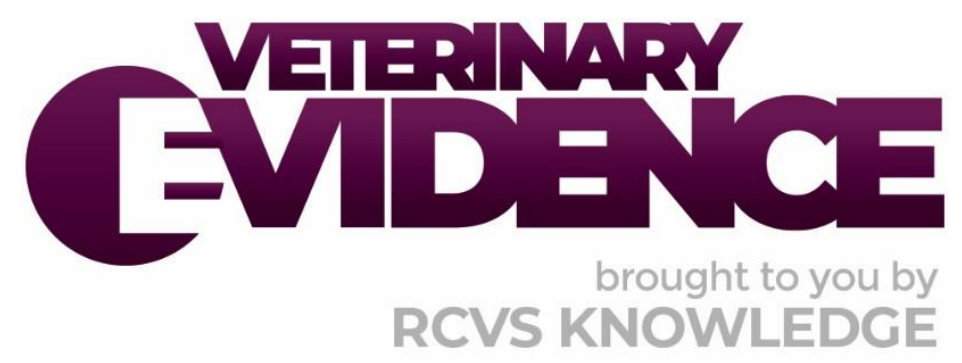

\title{
Should Levetiracetam or Imepitoin Be Used in Preference as Second-line Treatment in Pharmacoresistent Epileptic Cats?
}

\author{
A Knowledge Summary by
}

Sophie Elizabeth Wyatt BVetMed(Hons), MRVCS ${ }^{1^{*}}$

\footnotetext{
${ }^{1}$ Queen Mother Hospital for Animals, Royal Veterinary College, Hawkshead Lane, Hatfield, Hertfordshire, AL9 7TA

Corresponding Author (swyatt@rvc.ac.uk)
}

ISSN: 2396-9776

Published: 28 Jun 2019

in: Vol 4, Issue 2

DOI: http://dx.doi.org/10.18849/ve.v4i2.226

Reviewed by: Jacqueline Cole (BSc, BVetMed, MRCV) and Myra Forster-van Hijfte (CertVR, CertSAM, DipECVIM-cA, FRCVS)

Next Review Date: 25 Jan 2021 


\section{PICO question}

In adult cats with idiopathic epilepsy, which is poorly controlled with phenobarbital monotherapy, should levetiracetam or imepitoin be used in preference as a second line treatment in order to reduce seizure frequency?

\section{Clinical bottom line}

There is currently insufficient evidence to reliably determine whether levetiracetam or imepitoin should be used in preference as a second line treatment for the management of cats with refractory idiopathic epilepsy. There is weak evidence however to suggest clinical efficacy of levetiracetam and imepitoin in management of cats with idiopathic epilepsy. Further studies which evaluate and directly compare the efficacy of second line anticonvulsants in feline epilepsy are needed.

\section{Clinical Scenario}

A five-year-old female neutered cat is presented to you for ongoing management of presumed idiopathic epilepsy. The cat has suffered generalised seizures since she was approximately 18 months of age, and despite long-term therapy with phenobarbital anticonvulsant medication, the cat's seizure frequency has continued to increase with time. Based on recent patient serum phenobarbital concentrations, the dose of phenobarbital cannot be safely increased further. The owner has consulted internet forums and suggests you try a new 'wonder drug' named imepitoin. After consulting a colleague however, they suggest levetiracetam is a better second line treatment in this case. Of the two drugs, what is the next best option for successful pharmacological management of this cat's seizure episodes?

\section{The evidence}

Three studies of varying relevance to the PICO were reviewed including one systematic review and two uncontrolled prospective clinical trials. Although the studies provide evidence of the clinical efficacy of both levetiracetam and imepitoin, the strength of the evidence is low. Only one study specifically evaluated efficacy of levetiracetam as an adjunct to phenobarbital, and no direct comparison to date has been made between efficacy of levetiracetam or imepitoin as a second line anticonvulsant.

\section{Summary of the evidence}

Charalambous et al. (2018)

\begin{tabular}{|r|l|}
\hline Population: & Cats with confirmed or presumed idiopathic epilepsy, varying breeds \\
\hline Sample size: & 239 cats [systematic review of 40 studies] \\
\hline Intervention details: & $\begin{array}{l}\text { Studies were grouped based on the antiepileptic drugs evaluated } \\
\text { and the overall quality of evidence. Details of the drugs doses, } \\
\text { treatment period, pre and post-treatment seizure frequency, and } \\
95 \% \text { confidence interval of the successfully treated study population } \\
\text { were provided. }\end{array}$ \\
\hline Study design: & Systematic review \\
\hline Outcome studied: & Objective: Individual studies were evaluated based on the quality of \\
\hline
\end{tabular}




\begin{tabular}{|c|c|}
\hline Main findings: & $\begin{array}{l}\text { evidence (study design, size of study population, enrolment of study } \\
\text { subjects, overall risk of bias) and outcome measures reported, } \\
\text { including the proportion of cats with } \geq 50 \% \text { reduction in seizure } \\
\text { frequency. }\end{array}$ \\
\hline (relevant to PICO question): & $\begin{array}{l}\text { Risk of bias was high in } 2 / 5 \text { studies relevant to the PICO } \\
\text { question. }\end{array}$ \\
- & $\begin{array}{l}\text { Disease characterisation was variably defined in all studies } \\
\text { relevant to the PICO question. }\end{array}$ \\
- $\begin{array}{l}\text { Small (20-50 cats) or very small (< } 10 \text { cats) populations were } \\
\text { included in } 4 / 5 \text { studies relevant to the PICO question. }\end{array}$ & $\begin{array}{l}\text { There was weak evidence to support efficacy of } \\
\text { levetiracetam and imepitoin in terms of seizure reduction in } \\
\text { cats with idiopathic epilepsy. }\end{array}$ \\
\hline Limitations: & $\begin{array}{l}\text { The limitations in this review are intrinsically derived from } \\
\text { the studies included and evaluated. } \\
\text { Levetiracetam and imepitoin were evaluated in only five of } \\
\text { the } 40 \text { studies included in the review (i.e. } 51 \text { cats) and only } \\
\text { two of these studies considered levetiracetam in } \\
\text { combination with phenobarbital. }\end{array}$ \\
\hline
\end{tabular}

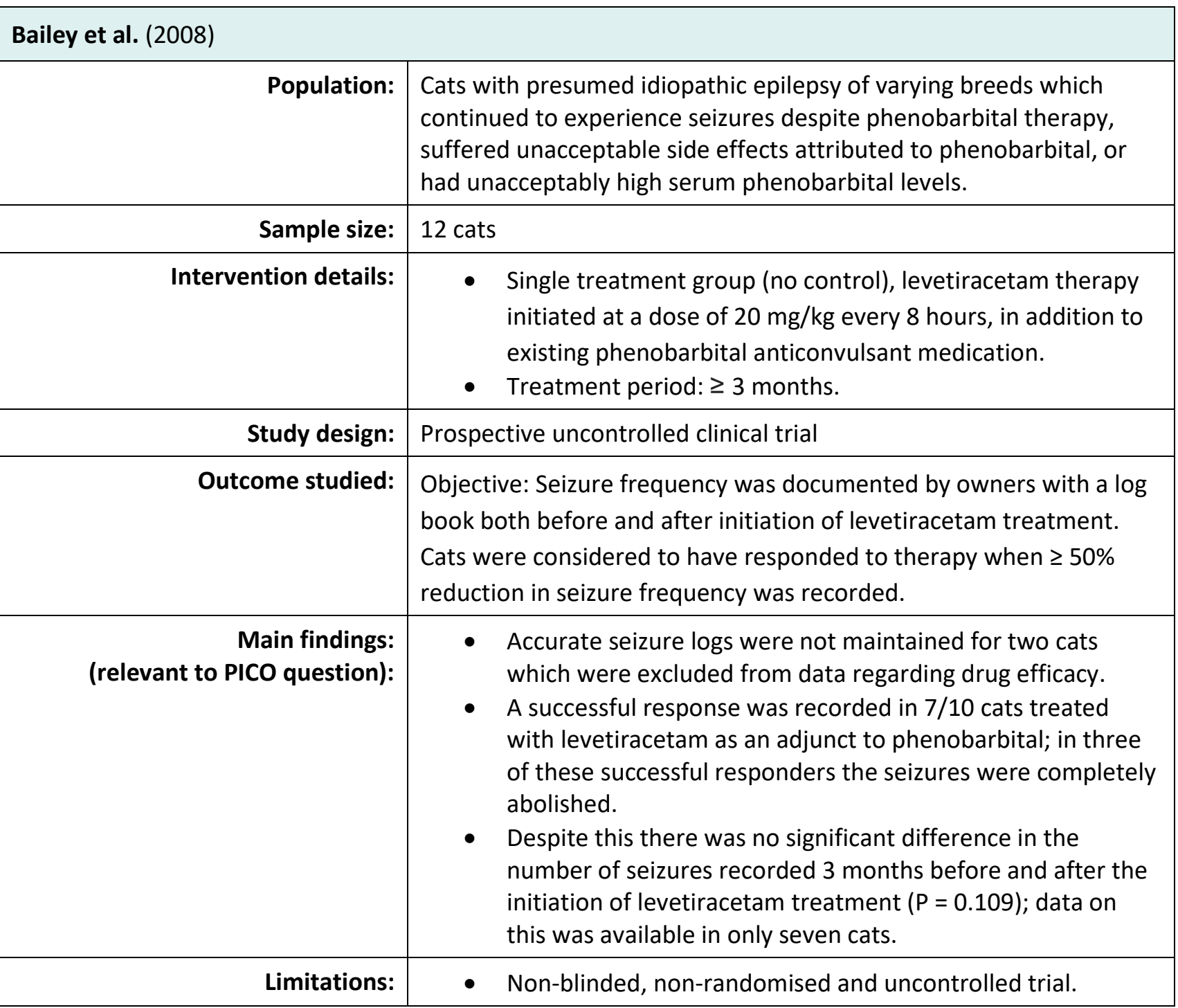




\begin{tabular}{|l|l|}
\hline - & Small study population. \\
- & Precise doses of concurrent phenobarbital treatment and \\
corresponding serum levels were not reported. & Outcome measure was recorded by lay personnel (i.e. \\
- & Owners) and therefore may not be entirely representative. \\
Variable inclusion criteria (i.e. $2 / 12$ cats were included on \\
basis they had unacceptable side effects attributed to \\
phenobarbital or had unacceptably high serum \\
phenobarbital levels), therefore not a completely \\
homogenous study population. \\
$\begin{array}{l}\text { Owners documented seizure frequency and thus were } \\
\text { responsible for measuring outcome data; this is open to bias } \\
\text { but realistically there are no other reliable and validated } \\
\text { methods for recording seizures long-term in a home } \\
\text { environment. }\end{array}$ \\
\hline
\end{tabular}

\begin{tabular}{|c|c|}
\hline \\
\hline \multicolumn{2}{|c|}{$\begin{array}{l}\text { Engel et al. (2017) } \\
\qquad \text { Population: }\end{array} \begin{array}{l}\begin{array}{l}\text { Epileptic cats with } \geq 2 \text { seizures within the preceding } 2 \text { weeks of study } \\
\text { enrolment, } \geq 9 \text { months of age. }\end{array}\end{array}$} \\
\hline Sample size: & Eight cats \\
\hline Intervention details: & $\begin{array}{l}\text { - Single treatment group (no control), imepitoin monotherapy } \\
\text { initiated at a dose of } 30 \mathrm{mg} / \mathrm{kg} \text { every } 12 \text { hours. } \\
\text { - Treatment period: } \geq 8 \text { weeks. }\end{array}$ \\
\hline Study design: & Prospective uncontrolled clinical trial \\
\hline Outcome studied: & $\begin{array}{l}\text { Objective: Animals with } \geq 8 \text { weeks of seizure freedom reported as } \\
\text { treatment success, } \geq 50 \% \text { reduction in seizure frequency reported as } \\
\text { partial success. Seizures were recorded by owners in a patient diary. }\end{array}$ \\
\hline $\begin{array}{l}\text { Main findings: } \\
\text { (relevant to PICO question): }\end{array}$ & $\begin{array}{l}\text { - } 4 / 8 \text { cats ( } 50 \%) \text { experienced treatment success, } 1 / 8 \text { cats } \\
\text { (12.5\%) experienced partial success, } 2 / 8 \text { cats }(25 \%) \\
\text { continued seizuring without success, and } 1 / 8 \text { cats was lost to } \\
\text { follow-up. } \\
\text { - There was a significant reduction in number of seizures per } \\
\text { month following initiation of imepitoin treatment ( } P \text { = } \\
\text { 0.0313). } \\
\text { One of the two study cats which failed to respond received } \\
\text { additional phenobarbital at a dose of } 1 \mathrm{mg} / \mathrm{kg} \text { every } 12 \\
\text { hours and attained seizure freedom until the point of last } \\
\text { recorded follow-up. }\end{array}$ \\
\hline Limitations: & $\begin{array}{l}\text { - Non-blinded, non-randomised and uncontrolled trial. } \\
\text { - Small study population. } \\
\text { - One cat was diagnosed with seizures secondary to feline } \\
\text { infectious peritonitis (FIP), and therefore not idiopathic. } \\
\text { responsible for measuring outcome data; this is open to bias } \\
\text { but realistically there are no other reliable and validated } \\
\text { methods for recording seizures long-term in a home } \\
\text { environment. }\end{array}$ \\
\hline
\end{tabular}




\section{Appraisal, application and reflection}

Although the strength of evidence is greatest with systematic reviews or meta-analysis, only one such study was included in this knowledge summary. ${ }^{1}$ Unfortunately however, the majority of findings from this particular study are not directly relevant to the PICO as they concern efficacy and safety of other anticonvulsants in feline epilepsy. For those aspects of the systematic review which were applicable to the PICO, the quality of evidence was low, risk of bias was frequently high, there was often incomplete outcome data, disease characterisation and study design, including drug dosages, were variable, and study group sizes were often small.

In addition, two uncontrolled prospective clinical trials were evaluated. One study specifically investigated the efficacy of adjunct treatment with levetiracetam in addition to phenobarbital in cats refractory to treatment. ${ }^{2}$ The other study evaluated imepitoin monotherapy, although in one 'non-responder' additional therapy with phenobarbital was initiated. ${ }^{3}$ The strength of evidence is low as both studies were non-blinded, nonrandomised and uncontrolled, with very small sample sizes. This limits the conclusions we can draw.

The regulatory aspects of the prescribing cascade should be considered during selection of treatment options for management of feline epilepsy; there is currently no licensed veterinary product for feline epilepsy in the UK. Phenobarbital and imepitoin is licensed in dogs only and levetiracetam is not licenced in cats or dogs. As per the prescribing cascade, authorised veterinary medicines where available should be used first. When unlicensed veterinary medicines are used, written consent should be obtained from the animal's owner. Therefore, the legal aspects of the cascade should be considered when prescribing drugs for management of feline epilepsy.

Although drug safety and tolerability were not specifically part of the PICO, this should be considered during selection of treatment options for management of feline epilepsy. In the study by Charalambous et al. (2018), the safety profile was regarded as strong for imepitoin, while the level of evidence for the safety profile of both phenobarbital and levetiracetam was weak.

No study to date has specifically evaluated efficacy of either levetiracetam or imepitoin as a monotherapy or second line anticonvulsant with a strongly convincing clinical effect. Such a study might utilise a randomised control trial design with clear inclusion criteria and objective outcome measures. More precisely, there are no studies which directly compare efficacy of levetiracetam or imepitoin. Therefore, there is insufficient evidence to answer the current PICO.

\section{Methodology Section}

\begin{tabular}{|c|c|}
\hline \multicolumn{2}{|l|}{ Search } \\
\hline $\begin{array}{r}\text { Databases searched and dates } \\
\text { covered: }\end{array}$ & $\begin{array}{l}\text { PubMed database accessed via NCBI, and CAB Abstracts accessed via } \\
\text { OVID platform }\end{array}$ \\
\hline Search strategy: & $\begin{array}{l}\text { PubMed: } \\
\text { (cat* OR feline* OR felid* OR felis) AND (epilepsy OR seizure*) AND } \\
\text { (levetiracetam OR imepitoin) } \\
\text { CAB abstracts: } \\
\text { (cat* OR feline* OR felid* OR felis) AND (epilepsy OR seizure* OR } \\
\text { epileptic) AND (levetiracetam OR imepitoin) }\end{array}$ \\
\hline Dates searches performed: & $25 / 01 / 2019$ \\
\hline
\end{tabular}




\begin{tabular}{|c|l|}
\hline Exclusion / Inclusion Criteria & \multicolumn{1}{|c|}{ Exclusion: } \\
\hline Inclusion: & $\begin{array}{l}\text { Single case reports, duplicate articles, review articles, book chapters } \\
\text { or sections, articles which did not directly evaluate the effect of } \\
\text { levetiracetam or imepitoin on seizure frequency in cats, articles } \\
\text { where the full text was not available in English language, articles } \\
\text { which were unavailable for review. }\end{array}$ \\
\hline $\begin{array}{l}\text { Original peer reviewed articles including case series, observational } \\
\text { or interventional studies, and systematic reviews which evaluate the } \\
\text { efficacy of imepitoin or levetiracetam in cats with idiopathic } \\
\text { epilepsy. }\end{array}$ \\
\hline
\end{tabular}

\begin{tabular}{|l|c|c|c|c|c|c|}
\hline \multicolumn{2}{|l|}{ Search Outcome } & Number \\
Database & $\begin{array}{r}\text { Excluded - } \\
\text { not } \\
\text { results } \\
\text { relevant to } \\
\text { the PICO }\end{array}$ & $\begin{array}{c}\text { Excluded - } \\
\text { review article }\end{array}$ & $\begin{array}{c}\text { Excluded - not } \\
\text { available in } \\
\text { English language } \\
\text { or unavailable } \\
\text { for review }\end{array}$ & $\begin{array}{c}\text { Excluded - } \\
\text { book chapters } \\
\text { or sections }\end{array}$ & $\begin{array}{c}\text { Total } \\
\text { relevant } \\
\text { papers }\end{array}$ \\
\hline PubMed & 32 & 22 & 7 & 0 & 0 & 3 \\
\hline CAB & 42 & 25 & 8 & 2 & 4 & 3 \\
\hline Abstracts & 42 & & & 3 \\
\hline Total relevant papers when duplicates removed
\end{tabular}

\section{CONFLICT OF INTEREST}

The author declares no conflicts of interest.

\section{REFERENCES}

1. Charalambous, M., Pakozdy, A., Bhatti, S.F.M., and Volk, H.A. Systematic review of antiepileptic drugs' safety and effectiveness in feline epilepsy. BMC Vet Res. 2018; 14(1). DOI:

https://doi.org/10.1186/s12917-018-1386-3

2. Bailey, K.S., Dewey, C.W., Boothe, D.M., Barone, G., and Kortz, G.D. Levetiracetam as an adjunct to phenobarbital treatment in cats with suspected idiopathic epilepsy. J Am Vet Med Assoc. 2008; 232(6): 867-872. DOI: https://doi.org/10.2460/javma.232.6.867

3. Engel, O., van Klopmann, T., Maiolini, A., Freundt-Revilla, J., and Tipold, A. Imepitoin is well tolerated in healthy and epileptic cats. BMC Vet Res. 2017; 13(1). DOI: https://doi.org/10.1186/s12917-017$\underline{1087-3}$ 


\section{EVIIDEFeE

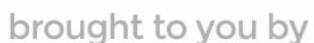 \\ RCVS KNOWLEDGE}

\section{Intellectual Property Rights}

Authors of Knowledge Summaries submitted to RCVS Knowledge for publication will retain copyright in their work, and will be required to grant RCVS Knowledge a non-exclusive license of the rights of copyright in the materials including but not limited to the right to publish, re-

publish, transmit, sell, distribute and otherwise use the materials in all languages and all media throughout the world, and to license or permit others to do so.

\section{Disclaimer}

Knowledge Summaries are a peer-reviewed article type which aims to answer a clinical question based on the best available current evidence. It does not override the responsibility

of the practitioner. Informed decisions should be made by considering such factors as individual clinical expertise and judgement along with patient's circumstances and owners' values. Knowledge Summaries are a resource to help inform and any opinions expressed within the Knowledge Summaries are the author's own and do not necessarily reflect the view of the RCVS Knowledge. Authors are responsible for the accuracy of the content. While the

Editor and Publisher believe that all content herein are in accord with current recommendations and practice at the time of publication, they accept no legal responsibility

for any errors or omissions, and make no warranty, express or implied, with respect to material contained within.

For further information please refer to our Terms of Use.

RCVS Knowledge is the independent charity associated with the Royal College of Veterinary Surgeons (RCVS). Our ambition is to become a global intermediary for evidence based veterinary knowledge by providing access to information

that is of immediate value to practicing veterinary professionals and directly contributes to evidence based clinical decision-making.

\section{https://www.veterinaryevidence.org/}

RCVS Knowledge is a registered Charity No. 230886.

Registered as a Company limited by guarantee in England and Wales No. 598443.

Registered Office: Belgravia House, 62-64 Horseferry Road, London SW1P 2AF

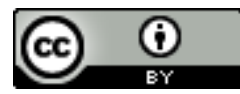

This work is licensed under a Creative Commons Attribution 4.0 International License 